\title{
Environmental Consequence of Trade Openness for Environmental Goods
}

\author{
J.M.D.D.J. de Alwis ${ }^{1}$
}

\begin{abstract}
With the increasing concerns on detrimental environmental effects of world trade, WTO member countries in 2001 called for reduction or elimination of tariffs and non-tariffs barriers on Environmental Goods and Services (EGS) claiming that would improve environmental protection and economic development simultaneously. The study investigated the impact of opening trade of EGS on environmental quality estimating pollution functions of Sulphur Dioxide $\left(\mathrm{SO}_{2}\right)$, Nitrogen Oxides $\left(\mathrm{NO}_{x}\right)$ and Carbon Dioxides $\left(\mathrm{CO}_{2}\right)$ using cross country data for 62 countries. Estimated $\mathrm{SO}_{2}$ pollution function revealed that elimination of tariff on EGS trade result in falling $\mathrm{SO}_{2}$ emissions in comparison to increasing $\mathrm{SO}_{2}$ pollution as a result eliminating tariff on non EGS trade. Findings formally support for the liberalization of EGS. Falling of $\mathrm{SO}_{2}$ pollution due to elimination of tariff on EGS is due to differences in countries' capital-labour endowments. The findings suggests that falling pollution due to EGS trade liberalization has no relationship with the income level of the countries, but favour capital abundant countries in reducing the pollution emissions.
\end{abstract}

\section{Introduction}

A green economy can be understood as one in which environmental and social costs are internalized into the production and consumption decision-making, pollution levels are made compatible with sink functions of nature, both upcoming growth and existing stocks of capital are subjected to transformation without or reducing additional harm to socio-environmental systems.

Green Economy emerged as a new potential development engine of the globe from the perspective of Development, Environment and Economic objectives (UNEP, 2011) has several important international dimensions. One is the role that international trade can play contributing towards a green economy. It is imperative as the international trade has become a powerful driver of economic growth.

\footnotetext{
${ }^{1}$ Senior Lecturer, Department of Agricultural Economics and Business Management, Faculty of Agriculture, University of Peradeniya, Sri Lanka.
} 
Global trade got its first impetus from the industrial revolution in the late eighteenth and early nineteenth century and there was a dramatic rise in world trade volumes in the twentieth century. From 1990 to 2007, the world's export volume has multiplied by a factor of three and the share of exports in the world GDP has increased from about $12 \%$ to $21 \%$ (WTO, 2009). World trade expansion and increasing economic openness has given rise to concerns about possible detrimental effects on the environment. Consequently, pressures have mounted to use trade instruments, such as North American Free Trade Agreement (NAFTA) and Uruguay Round of the General Agreement on Tariffs and Trade (GATT). With the transformation of the General Agreement on Tariffs and Trade (GATT) into the World Trade Organization (WTO), the WTO sought to address the issue of trade and the environment through a series of discussions and deliberations among its members in the standing committee, i.e. the Committee on Trade and Environment. As a result, the WTO's Doha Ministerial Declaration mandated specific negotiations on the trade and environment issue (Clause 31 and 32 of Doha Ministerial declaration). The paragraph 31 (iii) of the Doha mandate, agreed by all WTO members in 2001 during the Ministerial Conference held in Doha, Qatar, called for a reduction or as appropriate elimination of tariffs and non-tariffs barriers on Environmental Goods and Services (EGS).

The EGS industry consist of activities which produce goods and services to measure, prevent, limit, minimize or correct environment damage to water, air and soil as well as problems related to waste, noise and ecosystems. This includes cleaner technologies, products and services that reduce environmental risk and minimize pollution (OECD, 1992). After discussions and deliberations among member countries, WTO in 2011 identified 408 products at HS six digit level as general list of EGS, of which a core list of 26 EGS as a starting point for discussion. Despite the universally accepted definition, the EGS identified by WTO are subjected to the WTO negotiations on trade liberalization.

\section{Research Problem and Objective}

The WTO has been claiming that trade liberalization in environmental goods and services (EGS) would benefit both developed and developing countries; it would allow simultaneously environmental protection improvement and economic development where polluting firms in developing countries, that mainly import EGS, will likely increase their abatement demand as a result of reduced prices stemming from import tariff cuts. In turn, this decrease in compliance costs would likely induce local governments to put in place more ambitious environmental standards and reduction of pollution in developing countries. 
In trade liberalization literature, the pollution heaven hypothesis and the factor endowment hypothesis predict that openness to trade will alter the composition of national output in a manner that depends on a nation's comparative advantage considering comparative advantage to be a function of country's endowment of capital, labour and pollution (environment regulation).

The pollution haven hypothesis (or pollution haven effect) posits that jurisdictions with weak environmental regulations - 'pollution havens' - will attract polluting industries relocating from more stringent locales. The premise is intuitive: environmental regulations raise the cost of key inputs to goods with pollution-intensive production, and reduce jurisdictions' comparative advantage in those goods. If EGS trade liberalization would reduce the cost of regulation in countries with weak environmental regulations, imposition of more stringent regulations and further reduction of pollutions could be predicted.

In contrast, the factor endowment hypothesis/the pure capital-labour effect (KLE) predicts that considering the sectors' capital intensity and its' pollution intensity, in the presence of trade liberalization, the KLE would result in the capital abundant countries specializing in capital intensive, and therefore pollution intensive production and labour abundant countries specializing on labour intensive relatively cleaner production. Accordingly, the environmental consequence of liberalization of EGS would depend on how EGS could influence the pollution intensity of the capital intensive sectors of the economies.

However, there is hardly any empirical investigations on environmental consequences of EGS trade liberalization on both developed and developing countries. Therefore, this study empirically investigates the impact of opening trade of EGS on environmental quality by estimating the pollution functions of $\mathrm{CO}_{2}, \mathrm{NO}_{\mathrm{x}}$ and $\mathrm{SO}_{2}$ pollutants.

\section{Literature}

\section{International Trade Theories}

The theory on international trade predicts that, trade and environment can be mutually compatible and perhaps even reinforcing, whereas trade liberalization bring economic benefits that can be distributed so as to reduce poverty and protect the environment. 
David Ricardo showed that because countries face different costs to produce a similar product, if each country produce and then export the goods for which it has comparatively lower costs, then all parties benefit.

The effects of comparative advantage on factors of production were developed in 'Heckscher-Ohlin' model. It assumes the perfect competition in all countries, technology constant and readily available, same mix of goods and services, and factor of production (capital and labour) can move freely. Within this framework, Stolper-Samuelson theory predicts that international trade can increase the price of products and therefore the welfare in which a country has a comparative advantage. In theory, the gains from trade accruing to "winning" sectors freed to exploit their comparative advantage have the possibility to compensate the losers of trade liberalization. In a perfect world, free trade and increasing export could be beneficial to all parties. These theories have been extended to conceptualize the trade and environment relationship and there are empirical investigations on direct and indirect effects of trade on environment (Gallagher, 2008).

\section{Trade Openness Impacts on Environmental Quality}

A useful framework for thinking about the direct effects of trade on environment has been proposed by Grossman and Alan Krueger (1995) to describe various impacts of any changes in an economy's fundamental variables - endowments, prices, technologies, and policies - on aggregate use of the environment. They identify three mechanisms by which trade and investment liberalization affect the environment: scale, composition and technique effects. Put in simplest terms, the amount of emissions an economy generates depends on three essential factors: the size of the economy, the share of output that is produced by emission-intensive ("dirty") sectors, and the degree of emissions intensity in those sectors.

The scale effect refers to an increase in emissions associated with a larger GDP, holding constant the relative mix of outputs and pollution intensities across sectors. That is, increase in all productive factors, everything else held constant, should raise pollution by the same percentage.

The composition effect refers to a change in the share of dirty goods in GDP, which may arise because of a price change favouring their production. With a constant scale of the economy and no change in emissions intensities per industry, this effect would increase total pollution.

The technique effect refers to a change in the amount of emissions per unit of output (emissions intensity) across sectors so that a higher pollution 
tax would induce firms to adopt cleaner technologies. The term technique effect generally refers to the idea that anything raising per-capita income in the economy generates an endogenous increase in environmental taxes, thereby reducing the pollution intensity of production. One important reason that a government would increase the environmental regulation is due to the demand for a cleaner environment as incomes rise, considering environmental health as a normal good.

\section{Empirical Evidences}

Based on this theoretical framework, Antweiler et al. (2001) proposed analytical framework for trade analysis (Copeland-Taylor framework) and using data on sulfur dioxide concentrations $\left(\mathrm{SO}_{2}\right)$ in 293 sites in 44 countries from the Global Environment Monitoring Project over the period 1971-1996. They decomposed emissions into scale (GDP), composition (capital-labour endowment ratios), and technique (real income) effects, interacting each with a measure of openness to trade. They found that international trade generates relatively minor changes in concentrations of air pollution when it alters the composition of output, but that the associated technique and scale effects reduce pollution. Overall they found that within their sample, openness to trade actually reduces sulfur dioxide concentrations on average. They obtained this conclusion by estimating a model highlighting the interaction of factor endowments and income differences in determining the pattern of trade.

First they distinguish empirically between the negative environmental consequences of scalar increase in economic activity i.e. scale effect and the positive environmental consequences of increase in income i.e. technique effect. Second, they devised a method for determining how trade-induced changes in the composition of output affect pollution concentrations. Here it allows how the trade openness affects the composition of output differently in different countries specializing in the sectors where they enjoy a comparative advantage.

Both the pollution heaven hypothesis and the factor endowment hypothesis predict that openness to trade will alter the composition of national output in a manner that depends on a nation's comparative advantage considering comparative advantage to be a function of country's endowment of capital, labour and pollution.

In particular, the specific effects generated by environmental regulation on trade comparative advantages, is the pollution haven hypothesis. It posits that jurisdictions with weak environmental regulations attract polluting industries relocating from more stringent locales. Race-to-the 
bottom discussions are plausible in the economic theory, where the Heckscher-Ohlin model provides the theoretical foundations by showing that regions will export goods that use locally abundant factors as inputs. Empirically, however, robust evidence that industries shift production to less stringent jurisdictions has proven elusive.

In contrast, the factor endowment hypothesis/the pure capital-labour effect (KLE) would see the composition effect determined by relative capital and labour endowments. Considering the sectors' capital intensity and its' pollution intensity (though less well understood), in the presence of trade liberalization, the KLE would result in the capital abundant countries specializing in capital intensive, and therefore pollution intensive and labour abundant countries specializing on labour intensive relatively cleaner production.

The empirical model used by the authors allows comparative advantage to be driven by capital and labour endowments instead of or as well as differences in environmental regulations. Furthermore, such environmental regulations are endogenously determined within the model by income differences and relative price changes. Given below is a brief outline of the model.

Assume a small economy with two goods $X$ and $Y$, with two factors of production capital $(K)$ and labour $(L)$. Assume industry $X$ is capital intensive thus pollution intensive generates pollution. $\mathrm{Y}$ is a labour intensive and clean good.

Assume existence of trade barriers. If $p$ is the relative price of $X$ then domestic price differ from world price $p w, p=\beta p w(1), \beta$ denotes trade frictions and $p w$ is the world relative price of $X$.

Authors decompose the pollution $(z)$ into scale, composition and technique effects,

$$
\hat{Z}=\hat{S}+\hat{\delta}+\hat{e}
$$

where ${ }^{\wedge}$ denotes the percentage change, ' $s$ ' is the scale effect, ' $\delta$ ' represents the share of pollution intensive good $X$ in total output, otherwise known as the composition effect, ' $e$ ' represents the pollution intensity of the dirty industry or the technique effect.

With further decomposition of the equation (1) they arrive at private sector's demand for pollution. Pollution demand is a positive function of 
scale, capital abundance, world price of dirty goods and is a negative function of a pollution tax. The degree of trade friction also affects pollution demand; the direction depends on whether the country is an exporter or importer of dirty goods. In the model pollution supply is determined by the price of polluting (pollution tax), in turn real income is a determinant of pollution tax, where increase in real per capita income increases the demand for environmental quality. Combining pollution demand and supply arrives at the reduced form equation,

$$
\hat{Z}=\gamma_{1}+\hat{S}+\gamma_{2} \hat{K}+\gamma_{3} \hat{I}-{ }_{4} \hat{T}+\gamma_{5} P^{w}+\gamma_{6} \hat{\beta}
$$

where all $r i$ are positive, $\mathrm{k}$ denotes the capital labour ratio $(K / L)$, I is real per capita income, $\mathrm{T}$ represents the country type. From the equation we can illustrate the direction of the trade induced composition effect vary.

For an exporter of dirty good, $\beta<1$, and as trade liberalized $\beta$ will increase and hence $\hat{\beta}>0$. Thus country with a comparative advantage in pollution intensive output, trade liberalization will increase emissions. For dirty goods importer $\beta>1$ and trade liberalization will mean $\hat{\beta}<0$. Thus for a country with comparative advantage in clean output, trade liberalization will reduce pollution.

This therefore derives an important result that holding other determinants constant, trade liberalization does not have unique relationship with emissions. Rather the effect of liberalization on environment will be country specific and depends crucially on a country's comparative advantage. The model therefore allows comparative advantage to be driven by pollution haven and or factor endowment motives.

Matthew and Elliot (2003) using the same theoretical and empirical framework of Antweiler et al. (2001), estimated the empirical model for four pollutants (SO2, CO2, NOx and water pollution taking a sample of 32 countries supported the findings of Antweiler et al. (2001).

\section{Empirical Evidence on EGS Trade}

Within the WTO there is no clear agreement among Members on definition and coverage of environmental goods. Based on APEC, OECD and UNCTAD definitions of EGS, member countries of WTO proposed EGS in the WTO discussions.

OECD: The EGS industry consists of activities which produce goods and services to measure, prevent, limit, minimize or correct environment damage 
to water, air and soil as well as problems related to waste, noise and ecosystems. This includes cleaner technologies, products and services that reduce environmental risk and minimize pollution.

APEC: The EGS are the products that are needed for a set of environmental functions.

UNCTAD: Environmental Preferrable Products (EPPS) as "products which cause significantly less environmental harm at some stage of their life cycle (production, processing, consumption, [or] waste disposal) than alternative products that serve the same purpose, or products the production and sales of which contribute significantly to the preservation of the environment".

Two broad categories of EGS have featured in the WTO discussions so far: traditional environmental goods, with the main purpose of addressing or remedying an environmental problem (e.g., carbon capture and storage technologies); and environmentally preferable products (EPPs), which include any product with certain environmental benefits arising either during the production, use or disposal stage relative to a substitute or like product. Figure 2 explains distinctions between these categories.

- Type A: Conventional environmental goods- Industrial goods used to provide environmental services to address pollution and waste water, soil and air.

- Type B: Environmentally preferable products-Industrial and consumer goods that have environmentally preferable characteristics relative to substitute goods.

The literature on EGS liberalization is mostly dominated by physical estimates of trade flows (OECD, 2005; Yoo and Kim, 2011). Veena (2008) in her study, examined the factors which could explain the flow of EGS using a gravity model treating economic size/GDP of the country, FDI, sector specific and national performance indicators and specific technical assistance as explanatory variables. The analysis pertains to those products in the "153 list" of WTO. 
Figure 2: $\quad$ Environmental goods

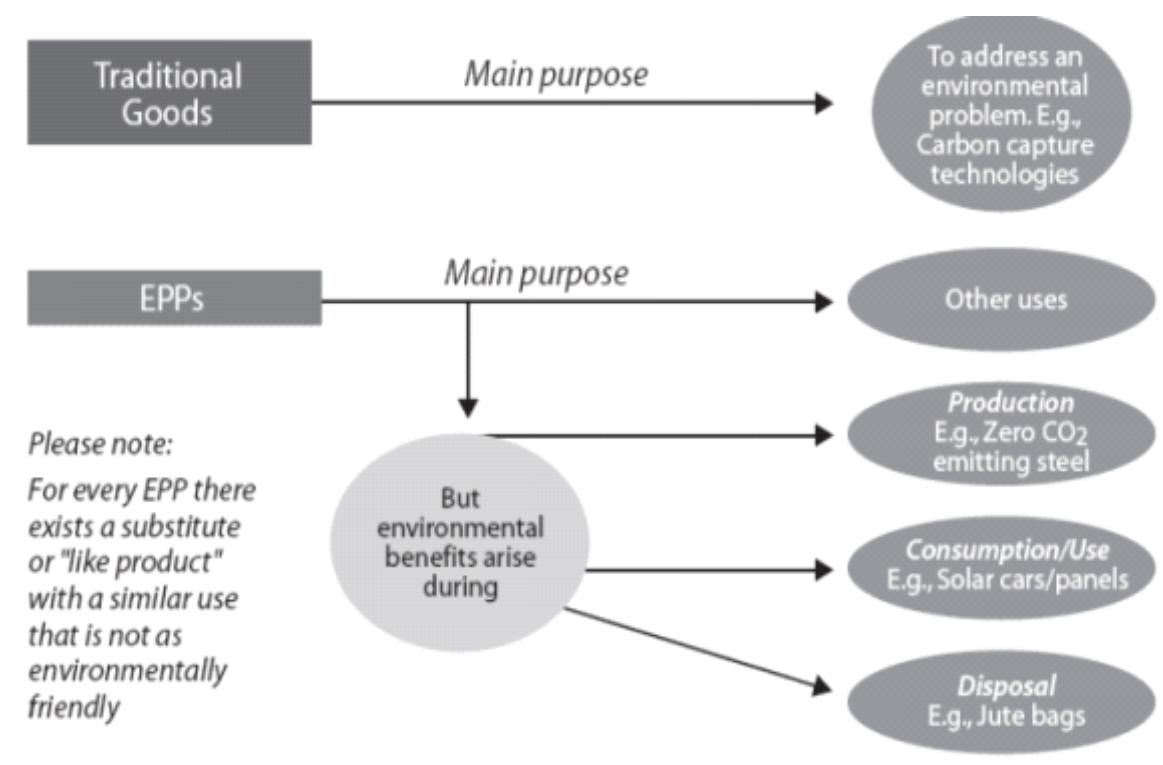

Source: Claro et al., 2007

Kalirajan (2012) using the same "153" list of WTO goods explored how regional cooperation can be achieved in trade and investment in EGS (Low Carbon Goods and Services). In his study he examined, what will be the magnitude of technology and investments in Low carbon Goods and Services (153 list) into Asia under a grand regional coalition scenario, limited cooperation scenario, and stand-alone scenario. He also investigated the impacts of behind the border constraints on potential export flows in low carbon goods and services in Asia and the potential options and challenges associated with grand coalition scenario. A stochastic frontier gravity equation is modelled using panel data set of 2000-2009 to explain the variations in total exports of the focus country by incorporating directly the influence of natural determinants: behind the border determinants, mutually induced determinants and explicit beyond the border determinants for a given level of existing implicit beyond the border determinants. 


\section{Method}

The present study tests following hypothesis.

Hypothesis 1: The literature suggests that opening of trade reduces pollution. This study argues that opening of trade for EGS have significantly higher improvement of environmental quality compared to opening of trade for non EGS.

Hypothesis 2: The general proposition is that there is high correlation between sector's capital intensity and the pollution intensity. Therefore, in the presence of trade liberalization, theory suggest that capital abundant countries specialize in pollution intensive and labour abundant countries specialize on cleaner products. This study argues that openness to EGs would be associated with falling pollution irrespective of their capital and labour endowments.

Hypothesis 3: The pure Environmental Regulation Effect (ERE) implies that developing countries will become pollution heavens and developed countries will specialize in clean production. This study argues that openness to EGs would cause falling pollution for both developed and developing countries.

\section{Empirical Model}

The three hypotheses are tested estimating the following two empirical models for three types of pollution emissions $\mathrm{CO}_{2}, \mathrm{NOx}$ and $\mathrm{SO}_{2}$ using cross sectional time series annual data of 62 countries for the period from 2001 to 2008. Model 1 is specified with basic theory of Antweiler et al. (2001). In model 2 quadratic terms of income and capital labour ratio is introduced to incorporate the Kuznet curve hypothesis and diminishing effect of capital accumulation. Description of variables is given in Table 1.

Model 1:

$$
\begin{aligned}
& E_{k t}=\alpha_{0}+\alpha_{1} K L_{k t}+\alpha_{3} I_{k t}+\alpha_{6} O^{b}{ }_{k t}+\alpha_{7} O^{b}{ }_{k t} K L_{k t}+\alpha_{8} O^{b}{ }_{k t}\left(K L_{k t}\right)^{2}+ \\
& \alpha_{9} O^{b}{ }_{k t} I_{k t}+\alpha_{10} O^{b}{ }_{k t}\left(I_{k t}\right)^{2}+\alpha_{11} O^{b}{ }_{k t} K L_{k t} I_{k t}+\alpha_{12} O_{k t}{ }_{k t}+\alpha_{13} O^{g}{ }_{k t} K L_{k t}+\alpha_{14} O_{k t} g_{k t}\left(K L_{k t}\right)^{2}+ \\
& \alpha_{15} O^{g}{ }_{k t} I_{k t}+\alpha_{10} O^{g}{ }_{k t}\left(I_{k t}\right)^{2}+\alpha_{11} O^{g}{ }_{k t} K L_{k t} I_{k t}+\varepsilon_{k t}
\end{aligned}
$$


Model 2:

$$
\begin{aligned}
& E_{k t}=\alpha_{0+}+\alpha_{1} K L_{k t}+\alpha_{2}\left(K L_{k t}\right)^{2}+\alpha_{3} I_{k t}+\alpha_{4}\left(I_{k t}\right)^{2}+\alpha_{5} K L I_{k t}+\alpha_{6} O^{b}{ }_{k t}+\alpha_{7} O^{b}{ }_{k t} K L_{k t}+\alpha_{8} O^{b} b_{k t}(K L k t)^{2}+ \\
& \alpha_{9} O^{b}{ }_{k t} I_{k t}+\alpha_{10} O^{b}{ }_{k t}\left(I_{k t}\right)^{2}+\alpha_{11} O^{b}{ }_{k t} K L_{k t} I_{k t}+\alpha_{12} O^{g}{ }_{k t}+\alpha_{13} O^{g}{ }_{k t} K L_{k t}+\alpha_{14} O^{g}{ }_{k t}\left(K L_{k t}\right)^{2}+ \\
& \alpha_{15} O^{g}{ }_{k t} I_{k t}+\alpha_{16} O^{g}{ }_{k t}\left(I_{k t}\right)^{2}+\alpha_{17} O^{g}{ }_{k t} K L_{k t} I_{k t}+\varepsilon_{k t}
\end{aligned}
$$

\begin{tabular}{|c|c|}
\hline Notation & Description of variables \\
\hline$K L_{k t}$ & Capital labour ratio \\
\hline$\left(K L_{k t}\right)^{2}$ & Square of capital labour ratio \\
\hline$I_{k t}$ & One period lagged per capita income \\
\hline$\left(I_{k t}\right)^{2}$ & Square of per capita income \\
\hline$K L I_{k t}$ & Cross product of KL and I \\
\hline$O^{g t}$ & Trade intensity(proxy for trade openness) for EGS \\
\hline$O^{b} k t$ & Trade intensity(proxy for trade openness) for non EGS \\
\hline$O_{k t}^{a} K L_{k t}$ & Interaction of trade intensity $(\mathrm{EG})$ with $\mathrm{K} / \mathrm{L}$ \\
\hline$O_{k t}^{a}\left(K L_{k t}\right)^{2}$ & Interaction of trade intensity(EG) with square of $\mathrm{K} / \mathrm{L}$ \\
\hline$O_{k t}^{a} I_{k t}$ & Interaction of trade intensity(EG) with I \\
\hline$O^{a}{ }_{k t}\left(l_{k t}\right)^{2}$ & Interaction of trade intensity(EG) with square of I \\
\hline$O_{k t}^{a} K L_{k t} I_{k t}$ & Interaction of trade intensity(EG) with I and $\mathrm{K} / \mathrm{L}$ \\
\hline$O_{k t}^{b} K L_{k t}$ & Interaction of trade intensity (NEG) with $\mathrm{K} / \mathrm{L}$ \\
\hline$O_{k t}^{b}\left(K L_{k t}\right)^{2}$ & Interaction of trade intensity(NEG) with square of $\mathrm{K} / \mathrm{L}$ \\
\hline$O_{k t}^{b} I_{k t}$ & Interaction of trade intensity(NEG) with I \\
\hline$O_{k t}^{b}(I k t)^{2}$ & Interaction of trade intensity(NEG) with square of I \\
\hline$O_{k t}^{b} K L_{k t} I_{k t}$ & Interaction of trade intensity(NEG) with I and $\mathrm{K} / \mathrm{L}$ \\
\hline$\varepsilon_{k t}$ & Error \\
\hline
\end{tabular}

Table 1: $\quad$ Description of variables 


\section{Data and Data Sources}

Annual data for the period from 2001 to 2008, of 62 countries consisting 25 high income countries, 15 upper middle income countries, 14 lower middle income and 8 lower income countries for 8 years from 2001 is used for the analysis. The study adopted cross sectional analysis taking the country specific means of the all variables, Ordinary Least Square regression estimation using STATA 2011 statistical package.

Trade data of 320 EGS under the categories of air pollution control, renewable energy, environmental technologies and energy efficiency technologies designated in WTO list 2011 were used as the EGS. These goods were categorized according six digit HS code. Trade data(EGS and non EGS trade data) were gathered from online UN COMTRADE Trade Statistics data base(http://comtrade.un.org/). Trade intensities were calculated using trade (export +import) and GDP. Capital labour ratios were calculated using physical capital stock and the labour force data. Physical stock data are not readily available for each country for the period from 2001-2008. Compiled data set of Physical capital stock for period from 1950 to 1990 (Vikram and Dhareshwar, 1993) was used to calculate the physical capital stock for the countries under consideration for the period from 2001 to 2008. For the calculation, this study used the method adopted by Arslanalp et al. (2011) to calculate physical capital stock using gross capital formation (current US\$) data available in World Bank Development Indicators data base. National emissions of $\mathrm{CO}_{2}, \mathrm{SO}_{2}$, and $\mathrm{NO}_{\mathrm{x}}$ data were obtained from the data base of Global Emissions Initiative, Emissions of atmospheric Compounds \& Compilation of Ancillary Data (http://eccad.sedoo.fr/eccad_extract_interface/JSF/page_meta.jsf) were used. GDP, GNP, Population, Labour force, Gross capital formation data obtained from World Bank Development Indicators database 2012 (http://data.worldbank.org/data-catalog/world-development-indicators).

\section{Results}

The annual average EGS trade (320 selected EGS) value is estimated at 9000 Million US\$ and has increased over the years from year 2001 to year 2008 (Figure 1). As shown in Figure 2, trade of EGS under category of "air quality", increased over the years. As depicted in Figure 3 below, upper middle income countries' imports have increased over the years than exports and exports of low income countries increased over the years. 
Figure 1: $\quad$ EGS tradefrom 2001-2008

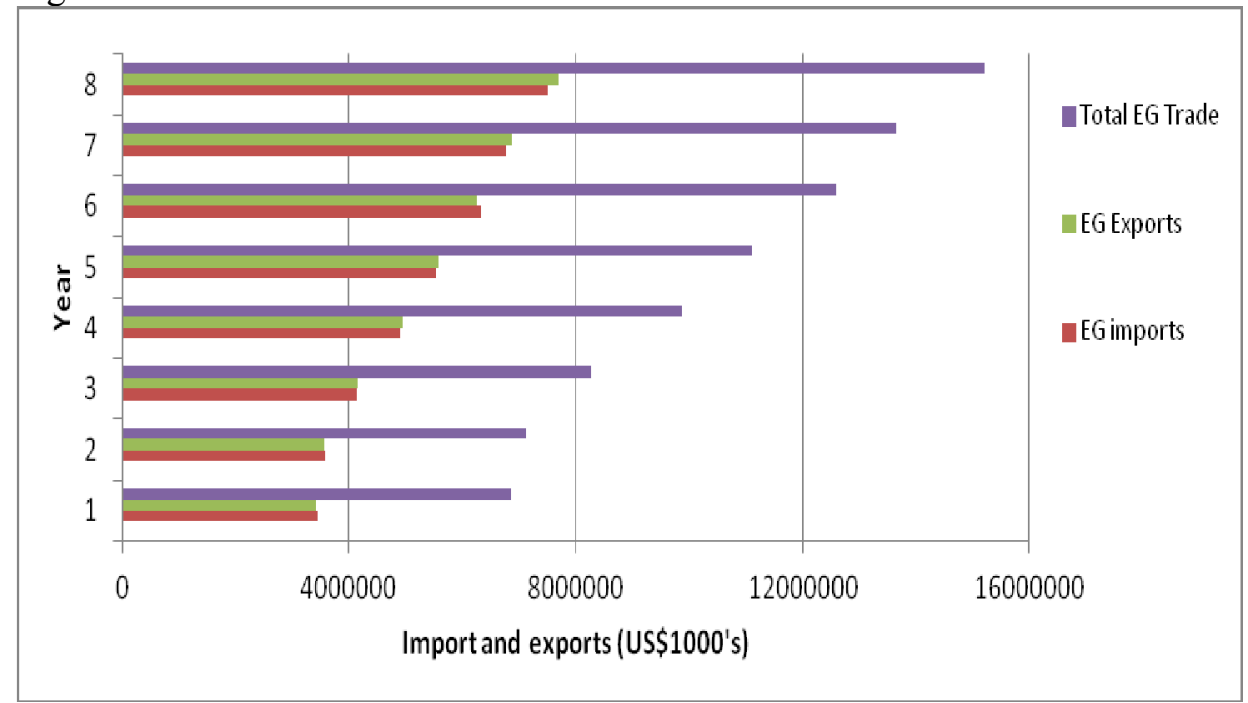

Figure 2: $\quad$ Import and export of selected EGS by categories

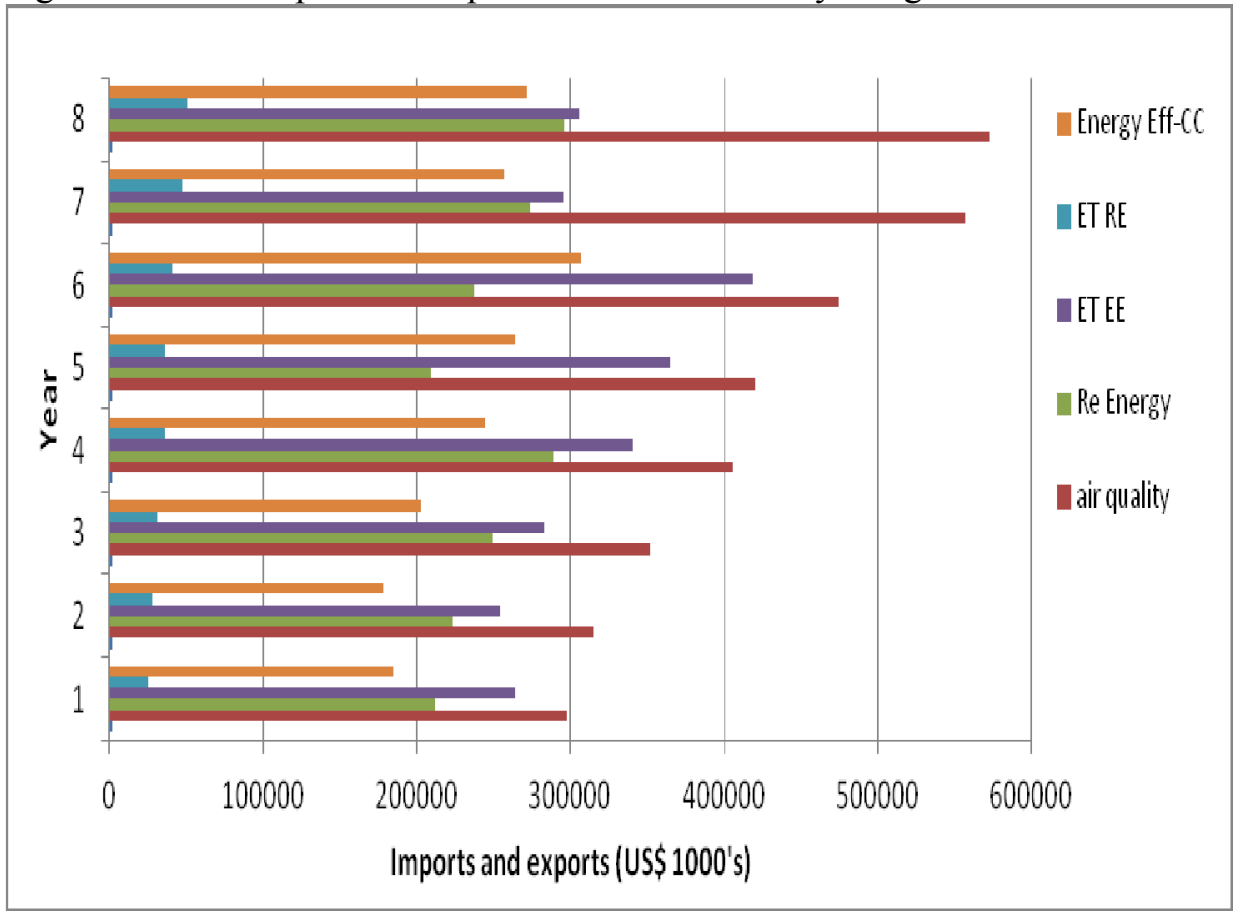


Figure 3: $\quad$ Value of EGS trade by country categories

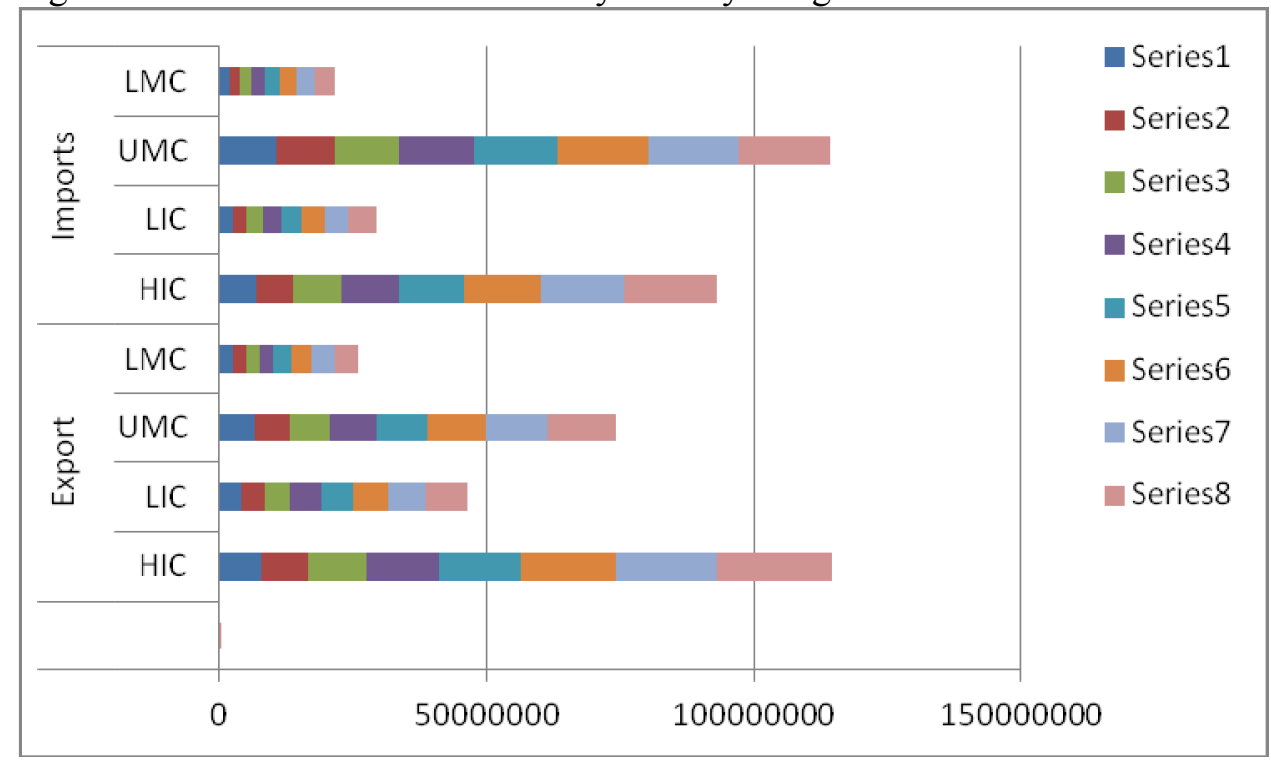

*Series in the legend indicates the years from 2001-2008

\section{Empirical Estimation of Pollution Functions}

Table 2 and 3 summarize the regression results. The average per capita emissions revealed in data are comparable to the data reported in other sources. According to the summary statistics, trade of non EGS compared is approximately 6 times of the EGS trade in an average country.

Table 2:

Statistical summary

\begin{tabular}{|c|c|c|c|}
\hline Variable & $\begin{array}{l}\text { Number of } \\
\text { observations }\end{array}$ & Mean & Units \\
\hline $\begin{array}{l}\text { Environmental Goods } \text { trade } \\
\text { Intensity }\end{array}$ & 496 & 67.8 & $\begin{array}{l}\text { Trade (in dollars) per } \\
\text { million dollars of GDP }\end{array}$ \\
\hline $\begin{array}{l}\text { Non Environmental goods } \\
\text { intensity }\end{array}$ & 496 & 593.9 & $\begin{array}{l}\text { Trade (in dollars) per } \\
\text { million dollars of GDP }\end{array}$ \\
\hline Per capita income & 496 & 13506 & Dollars \\
\hline $\begin{array}{l}\text { Per labour capital stock (capital } \\
\text { labour ratio) }\end{array}$ & 496 & 51.84 & in million dollars \\
\hline Annual per capita $\mathrm{CO}_{2}$ emission & 496 & 11.72 & Giga grams \\
\hline Annual per capita $\mathrm{NO}_{\mathrm{x}}$ emission & 496 & 0.121 & Giga grams \\
\hline Annual per capita $\mathrm{SO}_{2}$ emission & 496 & 0.131 & Giga grams \\
\hline
\end{tabular}


Table 3: $\quad$ Empirical models for three pollutants $\mathrm{SO}_{2}, \mathrm{CO}_{2}$, and $\mathrm{NO}_{\mathrm{x}}$

\begin{tabular}{|c|c|c|c|c|c|c|}
\hline \multirow[t]{2}{*}{ Variable } & \multicolumn{2}{|c|}{ Determinants of $\mathrm{CO}_{2}$} & \multicolumn{2}{|c|}{ Determinants of $\mathrm{NO}_{\mathrm{x}}$} & \multicolumn{2}{|c|}{ Determinants of $\mathrm{SO}_{2}$} \\
\hline & $\begin{array}{l}\text { Model } 2 \\
\text { Coefficient }\end{array}$ & $\begin{array}{l}\text { Model 1 } \\
\text { Coefficient }\end{array}$ & $\begin{array}{l}\text { Model } 2 \\
\text { Coefficient }\end{array}$ & $\begin{array}{l}\text { Model1 } \\
\text { Coefficient }\end{array}$ & $\begin{array}{l}\text { Model2 } \\
\text { Coefficient }\end{array}$ & $\begin{array}{l}\text { Model 1 } \\
\text { Coefficient }\end{array}$ \\
\hline I & $\begin{array}{c}1667.387 \\
(0.97)\end{array}$ & $\begin{array}{c}3118.848^{* * *} \\
(2.9)\end{array}$ & $\begin{array}{c}-48.430 * * * \\
(-3.39)\end{array}$ & $\begin{array}{c}-16.964 * \\
(-1.89)\end{array}$ & $\begin{array}{c}44.108 * * \\
(1.95)\end{array}$ & $\begin{array}{c}23.685^{*} \\
(1.69)\end{array}$ \\
\hline $\mathbf{I}^{2}$ & $\begin{array}{l}0.021 \\
(0.73)\end{array}$ & & $\begin{array}{c}0.0006^{* * * *} \\
(2.45)\end{array}$ & & $\begin{array}{c}-0.0005 \\
(1.34)\end{array}$ & \\
\hline $\mathbf{K L}^{2}$ & $\begin{array}{c}-2389.969 * * * \\
(2.38)\end{array}$ & & $\begin{array}{c}-27.534 * * * \\
(3.31)\end{array}$ & & $\begin{array}{l}-5.711 \\
(0.43)\end{array}$ & \\
\hline KL & $\begin{array}{c}-383812.1 \\
(0.57)\end{array}$ & $\begin{array}{c}-898778.7 * \\
(-1.73)\end{array}$ & $\begin{array}{c}17211.41 * * * \\
(3.06)\end{array}$ & $\begin{array}{c}6654.961 \\
(1.63)^{*}\end{array}$ & $\begin{array}{c}-12091.69 \\
(1.36)\end{array}$ & $\begin{array}{c}-5830.04 \\
(-0.86)\end{array}$ \\
\hline $\mathbf{K L} * \mathbf{I}$ & $\begin{array}{l}3.643 \\
(0.12)\end{array}$ & $\begin{array}{c}34.353^{*} \\
(1.66)\end{array}$ & $\begin{array}{c}-0.865 * * * \\
(3.43)\end{array}$ & $\begin{array}{c}-0.294 * \\
(-1.7)\end{array}$ & $\begin{array}{c}0.806 * * \\
(2.03)\end{array}$ & $\begin{array}{c}0.528 * * \\
(1.95)\end{array}$ \\
\hline $\mathbf{O}_{\mathrm{g}}$ & $\begin{array}{c}150.773 \\
(0.6)\end{array}$ & $\begin{array}{l}50.247 \\
(0.22)\end{array}$ & $\begin{array}{l}0.972 \\
(0.47)\end{array}$ & $\begin{array}{l}-1.272 \\
(-0.66)\end{array}$ & $\begin{array}{c}-8.706 * * * \\
(2.65)\end{array}$ & $\begin{array}{c}-7.188 * * * \\
(-2.38)\end{array}$ \\
\hline$O g * I$ & $\begin{array}{l}0.017 \\
(1.46)\end{array}$ & $\begin{array}{l}0.0215^{* * *} \\
\quad(2.27)\end{array}$ & $\begin{array}{c}0.00003 \\
(0.32)\end{array}$ & $\begin{array}{c}0.0002 * * \\
(2.11)\end{array}$ & $\begin{array}{c}0.00018 \\
(1.2)\end{array}$ & $\begin{array}{c}0.00005 \\
(0.45)\end{array}$ \\
\hline $\operatorname{Og} * I^{2}$ & $\begin{array}{c}-0.00000 * * * \\
(2.84)\end{array}$ & $\begin{array}{c}-0.00001 * * * \\
(-4.57)\end{array}$ & $\begin{array}{c}0.0000 * * * \\
(2.5)\end{array}$ & $\begin{array}{c}0.0000 \\
(0.75)\end{array}$ & $\begin{array}{c}-0.0000 \\
(0.45)\end{array}$ & $\begin{array}{c}-0.0000 \\
(0.00)\end{array}$ \\
\hline$O g * K L$ & $\begin{array}{l}-0.741 \\
(0.15)\end{array}$ & $\begin{array}{l}-4.834 \\
(-1.15)\end{array}$ & $\begin{array}{c}0.0723^{*} \\
(1.73)\end{array}$ & $\begin{array}{c}-0.0016 \\
(-0.05)\end{array}$ & $\begin{array}{c}-0.162 * * * \\
(2.46)\end{array}$ & $\begin{array}{c}-0.1289 * * * \\
(-2.35)\end{array}$ \\
\hline$O g * K L^{2}$ & $\begin{array}{c}0.016^{* * * *} \\
(2.53)\end{array}$ & $\begin{array}{l}0.0012 \\
(0.87)\end{array}$ & $\begin{array}{c}0.0002 * * * \\
\quad(4.56)\end{array}$ & $\begin{array}{c}0.00007 * * * \\
(6.28)\end{array}$ & $\begin{array}{l}0.0001 \\
(1.55)\end{array}$ & $\begin{array}{c}0.00008 * * * \\
(4.72)\end{array}$ \\
\hline$O g * K L * I$ & $\begin{array}{c}0.0002 \\
(1.26)\end{array}$ & $\begin{array}{c}0.0003 * \\
(1.83)\end{array}$ & $\begin{array}{c}0.000002 \\
(1.26)\end{array}$ & $\begin{array}{c}0.00004 * * * \\
(2.94)\end{array}$ & $\begin{array}{c}0.000004 \\
(1.54)\end{array}$ & $\begin{array}{c}0.000002 \\
(0.89)\end{array}$ \\
\hline $\mathbf{O}_{\mathrm{b}}$ & $\begin{array}{c}53378.52 \\
(0.9)\end{array}$ & $\begin{array}{c}56617.99 \\
(1.05)\end{array}$ & $\begin{array}{c}-806.195^{*} \\
(1.65)\end{array}$ & $\begin{array}{c}-449.9528 \\
(-1)\end{array}$ & $\begin{array}{c}1258.926^{*} \\
(1.83)\end{array}$ & $\begin{array}{c}749.888 \\
(1.07)\end{array}$ \\
\hline $\mathbf{O}_{b} * \mathbf{I}$ & $\begin{array}{c}-3.3940 \\
(1.25)\end{array}$ & $\begin{array}{c}-4.512 * * * \\
(-2.5)\end{array}$ & $\begin{array}{c}0.0729 \\
(3.24)\end{array}$ & $\begin{array}{c}0.035 * * \\
(2.32)\end{array}$ & $\begin{array}{c}-0.0802 * * \\
(2.26)\end{array}$ & $\begin{array}{c}-0.0424 * \\
(-1.79)\end{array}$ \\
\hline $\mathbf{O}_{b} * I^{2}$ & $\begin{array}{c}-0.00002 \\
(0.35)\end{array}$ & $\begin{array}{c}0.00002 \\
(1.11)\end{array}$ & $\begin{array}{c}-0.00001^{* * *} \\
(3.39)\end{array}$ & $\begin{array}{c}-0.000004 * * * \\
(-3.65)\end{array}$ & $\begin{array}{c}0.000009 \\
(1.5)\end{array}$ & $\begin{array}{c}0.0000001 \\
(0.7)\end{array}$ \\
\hline $\mathrm{O}_{\mathrm{b}} * \mathrm{KL}$ & $\begin{array}{c}990.0505 \\
(0.82)\end{array}$ & $\begin{array}{l}1481.9 \\
(1.45)\end{array}$ & $\begin{array}{c}-27.496 * * * \\
(2.73)\end{array}$ & $\begin{array}{c}-13.962 * \\
(-1.63)\end{array}$ & $\begin{array}{l}18.937 \\
(1.19)\end{array}$ & $\begin{array}{l}7.363 \\
(0.55)\end{array}$ \\
\hline $\mathrm{O}_{\mathrm{b}}{ }^{*} \mathrm{KL}^{2}$ & $\begin{array}{c}-11.9682 * * * \\
(2.89)\end{array}$ & $\begin{array}{c}-3.638^{*} \\
(-1.83)\end{array}$ & $\begin{array}{c}-0.0519 \\
(1.51)\end{array}$ & $\begin{array}{c}0.0244 \\
(1.47)\end{array}$ & $\begin{array}{c}-0.0856 \\
(1.58)\end{array}$ & $\begin{array}{c}-0.0338 \\
(-1.3)\end{array}$ \\
\hline $\mathbf{O}_{\mathrm{b}} * \mathbf{K L} * \mathbf{I}$ & $\begin{array}{c}-0.0338 \\
(-0.7)\end{array}$ & $\begin{array}{c}-0.062 * \\
(-1.75)\end{array}$ & $\begin{array}{l}0.0012 * * * \\
(2.99)\end{array}$ & $\begin{array}{c}0.0004^{*} \\
(1.65)\end{array}$ & $\begin{array}{c}-0.0015 * * * \\
(2.37)\end{array}$ & $\begin{array}{l}-0.001 \\
(-2.05)\end{array}$ \\
\hline Constant & $\begin{array}{c}-0.0000001 \\
(1.42)\end{array}$ & $\begin{array}{c}-0.0000002 \\
(-1.9)\end{array}$ & $\begin{array}{c}465460.8 * * * \\
(4.46)\end{array}$ & $\begin{array}{c}357121.2 \\
(0.77)\end{array}$ & $\begin{array}{c}29550.72 \\
(0.18)\end{array}$ & $\begin{array}{c}129122.2 \\
(0.87)\end{array}$ \\
\hline $\mathbf{R 2}$ & 0.18 & 0.17 & 0.24 & 0.22 & 0.1 & 0.09 \\
\hline $\mathbf{F}$ & $\begin{array}{c}6.48 \\
(0.000)\end{array}$ & $\begin{array}{c}6.91 \\
(0.000)\end{array}$ & $\begin{array}{c}8.99 \\
(0.000)\end{array}$ & $\begin{array}{c}9.17 \\
(0.000)\end{array}$ & $\begin{array}{c}3.25 \\
(0.000)\end{array}$ & $\begin{array}{c}3.47 \\
(0.000)\end{array}$ \\
\hline
\end{tabular}

*Indicates significance at $90 \%$ confidence interval

$* *$ indicated significance at $95 \%$ confidence interval

$* * *$ indicated significance at $99 \%$ confidence interval

Grams per capita emissions used in the analysis. 


\section{Determinants of $\mathrm{CO}_{2}$ Emissions}

Considering the number of variables of interest statistically significant, the model 1 better explains the $\mathrm{CO}_{2}$ emission function. Theory and empirical findings suggest a significant positive relationship between the scale of economies and pollution and, a negative relationship between lagged per capita income and pollution. In this study, the per capita income captures the net effect of scale and income effect.

Positive significant coefficient for per capita income in estimated model reveals that scale effect dominates the income effect and one dollar increase of per capita income increases $3118.84 \mathrm{~g}$ of per capita. In contrast to the positive coefficient of capital labour ratio expected in theoretical and empirical literature, negative significant coefficient in the model indicates reduction of $898 \mathrm{~kg}$ of per capita emission for additional million dollar of per labour capital stock. KLI captures the effect of income on pollution depending on the existing level of per labour capital stock and vice versa. The positive coefficient revealed indicates increasing $\mathrm{CO}_{2}$ pollution with the increase of income in countries with higher per labour capital stock. The joint effect is increase of $34.3 \mathrm{~g}$ of $\mathrm{CO}_{2}$ emissions.

Considering the trade openness variable, the estimated model achieved positive relationship for both EGS and non EGS trade intensities, where the coefficient for EGS is less than the non EGS, However both coefficients are statistically non-significant.

The significant positive coefficient of the interaction variable $(\mathrm{Og} * \mathrm{I})$ for EGS intensity indicates increases of $\mathrm{CO}_{2}$ pollution due to freer EGS trade in countries with higher income. However the joint impact is marginal which is at $0.021 \mathrm{~g}$ increase of $\mathrm{CO}_{2}$ emissions per capita.

The negative coefficient of variable $\mathrm{Ob}^{*} \mathrm{KL} 2$ indicates joint effect diminishing with an additional unit of per labour capital stock. The joint effect of $\mathrm{Ob}^{*} \mathrm{KL} * \mathrm{I}$ has a very marginal negative effect.

\section{Determinants of $\mathrm{NO}_{x}$ Emissions}

Model 2 better explains the $\mathrm{NO}_{\mathrm{x}}$ pollution function with variables of interest compared to model 1 . The statistically significant negative coefficient for per capita income in the model shows a falling of $48.4 \mathrm{~g}$ of $\mathrm{NO}_{\mathrm{x}}$ with one dollar increase of per capita income. This indicates dominant income effect over the scale effect. As expected in the theory, the positive coefficient of KL revealed indicates increase of $172.11 \mathrm{Kg}$ of $\mathrm{NO}_{\mathrm{x}}$ per increase of million dollar 
of per labour capital stock. An additional million dollars of per capita capital stock cause falling of $28 \mathrm{~g}$ per capita $\mathrm{NO}_{\mathrm{x}}$ emissions. The negative coefficient of KLI indicates falling NOx emissions with the increase of income in countries high per labour capital stock. However, the joint effect is very marginal where the impact is only $0.86 \mathrm{~g}$ of NOx emissions. Coefficient for trade openness for EGs is not significant and positive significant coefficient of the interaction EGs intensity with per capita capital stock indicates increasing $\mathrm{NO}_{\mathrm{x}}$ emissions by $0.07 \mathrm{~g}$ of per capita emission for opening trade for EGs with higher capital labour ratio. The variable Og*KL2 has positive coefficient indicates, additional unit of per labour capital stock has a diminishing effect on the joint effect of $O g^{*} \mathrm{KL}$. However the impact is very marginal. However, a negative significant coefficient is revealed for the non EGs trade intensity indicating a falling of $806 \mathrm{~g}$ of $\mathrm{NO}_{\mathrm{x}}$ per unit change of trade intensity (a dollar worth of non EGs trade per million dollar GDP) indicates that trade liberalization of non EGs trade reduces pollution. Negative significant coefficient of Interaction variable for non EGs intensity with per capita capital stock estimated falling emissions at $27.5 \mathrm{~g}$ for trade opening to non EGs goods associated with countries having higher per labour capital stock. The coefficient of interaction term of non EGs trade intensity, KL and I has a positive significant coefficient but with very marginal impact.

\section{Determinants of $\mathrm{SO}_{2}$ Emissions}

As many of the variables in the model 2 reveals significant coefficients, with a statistical significance of the model, the model 2 is selected for the $\mathrm{SO}_{2}$ emissions function. The positive significant coefficient for per capita income variable indicates that scale effect dominates income effect and there is an addition of $44 \mathrm{~g}$ of per capita emissions per dollar increase of per capita income. The positive coefficient of KLI indicates increasing $\mathrm{SO}_{2}$ emissions for the increase of income associated with high per labour capital stock. However, the joint effect is very marginal. The trade openness variable for EGs has a negative coefficient in compared to the positive coefficient revealed for non-environmental goods. An increasing dollar worth of imports and exports of EGs per million dollars of GDP causes falling 8.7 grams of per capita emissions compared to $1.25 \mathrm{kgs}$ of estimated emissions for opening trade for non EGS. The non-significant coefficient of the interaction variable for EGS intensity and income is not significant indicates there is no evidence to say that with liberalizing EGS trade, the impact on pollution originates due to income differences. The coefficient for joint effect of EGs trade intensity and per labour capital stock has a negative significant coefficient indicating the trade liberalization of EGs falling pollutions associated with capital abundant countries. However the impact is marginal with $0.16 \mathrm{~g}$ of per capita annual emissions of $\mathrm{CO}_{2}$. The joint effect 
of non EGs trade intensity and income has a negative significant coefficient indicates, with trade liberalizing for non EGS falling pollution for countries with high income. However impact is marginal as the coefficient is only 0.08 g per capita emissions. The coefficient of variable for joint effect of non EGS trade intensity, KL and I has a negative significant coefficient but with marginal impact.

\section{Summary, Conclusion and Policy Implications}

The study investigated the impact of opening trade of EGS on environmental quality in compared with the impacts of non EGS trade estimating three pollution function for $\mathrm{NO}_{\mathrm{x}} \mathrm{CO}_{2}$ and $\mathrm{SO}_{2}$. The study argues that; (1) opening of trade for EGS have significantly higher improvement of environmental quality in compared to openness of non EGs goods to trade (Hypothesis 1), (2) openness to EGS would be associated with falling pollution irrespective of their capital and labour endowments (Hypothesis 2) and (3) irrespective of the income (Hypothesis 3). The econometric model used; per labour capital stock (capital labour ratio), per capita income, and trade intensity of EGS and non EGs trade as a proxy for trade openness as basic explanatory variables and, interaction of variables introduced allowing joint effects. Pollution functions estimated using ordinary least square method with cross country eight year averages of data for 62 countries. According to estimated empirical models of three pollutants, estimated $\mathrm{SO}_{2}$ emissions function provides evidence for plausibility of hypothesis 1 and 3. Hypothesis 2 is not plausible according to the results. Estimation of $\mathrm{SO}_{2}$ pollution function finds that elimination of tariff on EGS trade result in falling of $\mathrm{SO}_{2}$ emissions compared to the increasing of $\mathrm{SO}_{2}$ pollution for eliminating tariff barriers on non EGs trade. It is estimated that, falling of 9 grams of per capita $\mathrm{SO}_{2}$ emissions for increase of one dollar worth of EGS trade per million dollar of GDP compared to the increase of 1.3 kilo grams of pollution associated with increase of one dollar worth of trade of non EGs trade per million dollars of GDP. The estimated $\mathrm{SO}_{2}$ function shows that falling of $\mathrm{SO}_{2}$ pollution due to elimination of tariff on EGS trade originates due to differences in capitallabour endowments. EGS trade liberalization has advantages for capital abundant countries in reducing the pollution emissions. Therefore, hypothesis 2 is not plausible. Further, non-significant coefficient revealed for interaction variable of EGS trade intensity and income indirectly supports the hypothesis 3. The empirical findings of this study formally supports for the liberalization of EGS as the net effect of the trade liberalization of EGS is negative compared to the trade liberalization of non EGS. However, trade liberalization of EGS favours the capital abundant north having the negative impact on emissions. Finally we find that free trade of EGS reduces the emissions, however liberalization may not be the only determinant of the EGS trade 
intensity. Other factors such as institutional quality, role of stringency of the environmental policy may also determine the volume of EGS trade and those could also be considered. The findings are plausible only for estimated emissions functions. Nevertheless, these findings are subjected to the selected categories of products in the WTO list and results can be misleading while asserting that trade intensity of EGS of any classification improves the environmental quality.

\section{References}

Antweiler, W., R. Copland, and M.S. Tayler (2001). Is Free Trade Good for the Environment? American Economic Review, 91(4):877-908.

Arslanalp, S., F. Bornhorst, and S. Gupta (2011). Investing in Growth, Finance \& Development, 48(1).

Cole, M.A., R.J.R. Ellliot (2003). Determining the Trade-Environment Composition Effect: the Role of Capital, Labour and Environment Regulations. Journal of Environmental Economics and Management, 46:363-383.

Gallagher, Kevin P. 2008, Handbook on Trade and Environment. Edward Elgar Publishing Inc., USA.

Kalirajan, K. (2012). Regional Cooperation towards Green Asia: Trade and Investment. ADBI Working Paper 350 (2012), Tokyo, Japan.

OECD (2005). Policy Brief: Opening Markets for Environmental Goods and Services. Retrieved from <http://www.oecd.org/trade/ environmentandtrade/35415839.pdf>.

OECD (1992). The OECD Environment Industry: Situation, Prospects and Government Policy, Paris.

UNCOMTRADE. (2012). http://comtrade.un.org/. Retrieved on August 10, 2012

United Nations Environment Program (2011). Green Economy Synthesis Report. <http://www.unep.org/pdf/green_economy_blue.pdf $>$.

Vikram, N. and A. Dhareshwar (1993). A New Database on Physical Capital Stock (1950 to 990): Sources Methodology and Results. Rivista de Analysisis Economica, 8(1):37-59. 
World Bank (2012). Report on Inclusive Green Growth: The Path Way to Sustainable Development. <http:/issuu.com/ world.bank.publications/docs/9780821395516>.

World Bank (2012). World Development Indicator Database. Retrieved on October, $2012<$ http://data.worldbank.org/data-catalog/worlddevelopment-indicators $>$.

WTO-UNEP (2009). Trade and Climate Change: WTO-UNEP Report, WTO, Geneva, Switzerland. <http://www.wto.org/english/res_e/booksp_e/ trade_climate_change_e.pdf $>$

Yoo, S.H. and J. Kim (2011). Paper Prepared for AKES Conference, POSCO Research Institute. <http://www.trade-environment.org/page/outputs/ egs/compendium_dec_2007.pdf.> 